\title{
模型実験による室内音圧分布の測定法
}

正会員 前川純 一*

第 1 図

ブラウン管連続撮影 による短音減衰波形 写真

$3.15 \mathrm{kc}$ 短音 $2 \mathrm{~ms}$ 5 回/秒

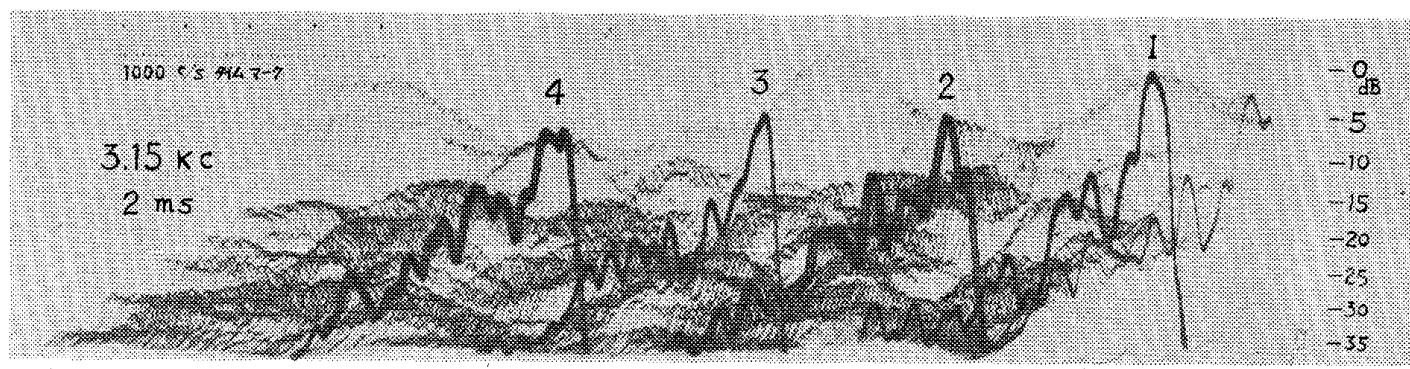

序 オーディトリウム(千数百席)の室形、拡散器等 の音響設計資料を得る目的で、1/25模型を用いる場合、如 何なる測定法が適当か、実験的に検討を行なった。ここで は音区分布測定結果の一部を示し若干の考察を行なう。

\section{1. 測定装置}

模型；縮尺 $1 / 25 、$ 橾ベニヤ $6 \mathrm{~m} / \mathrm{m}$ 厚、側壁、天井そ の他反射面はポリウレタン塗装、背壁、床（段にせず傾 斜面）等吸音面は上質フエルト $1 \mathrm{~m} / \mathrm{m}$ 厚貼り、音源； $3.15,6.3,12.5 \mathrm{kc}$ の $2 \mathrm{~ms}$ (実物 $125,250,500 \mathrm{c} / \mathrm{s}$ の $50 \mathrm{~ms}$ ) ・短音、および $1 / 3$ Oct. band Noise, スピーカ無 指向性ホーン型 (PT-01)、受音; コンデンサマイク (Brüel $4133+\mathrm{UA} 0052$ ) 外径 $13 \mathrm{~m} / \mathrm{m}, 1 / 3$ Oct. Filter, 対数圧縮增幅器、シンクロスコープ、同連続撮影装置、 および高速度レコーダ（2305）、マイクは移動車に乗せ 同期モータで約 $13 \mathrm{~mm} /$ 秒の速度で連続移動する。

\section{2. 短音音圧分布}

2.a）短音くり返し 5 回/秒、バルコニー前端から後 壁まで移動する間の短音減衰波形を、オシロペーパー（速 度 $5 \mathrm{~mm} /$ 秒) に連続撮影したものが第 1 図である。10 cm 毎に輝度を明るくして娍衰波形を見やすくした。これか ら残響時間も测定でき、エコー発見の可能性もある。

2.b）同じ状態で Brüel のレコーダで記録したもの が第 2 図 $\mathbf{A}$ であり、短音回数を多くしペン速度を変え て第 2 図 B が得られた。いずれも第1図とはあまり似 ていない。

\section{3：定常音圧分布}

$1 / 3$ Oct. band Noise による定常状態に打ける Brüel のレコーダーペン速度 (W.S.) $63 \mathrm{~dB} / \mathrm{sec}$ の記録が第 3 図である。

\section{4. 考 察}

短湆音玨分布は、Brüel のレコーダでは測定できな い。これはペンの慣性のためであろう。ある状態の同じ 位置で、各周波数の短音減衰波形のエンベロープと、定 常音圧分布とをスケールを合せて写し比較したものの一 部が第 4 図である。乙れらの図から若えうるととは
A. $3.15 \mathrm{kc}$ 短竟 $2 \mathrm{~ms} 5$ 回/秒， Brüel W.S. $250 \mathrm{~dB} / \mathrm{sec}$.

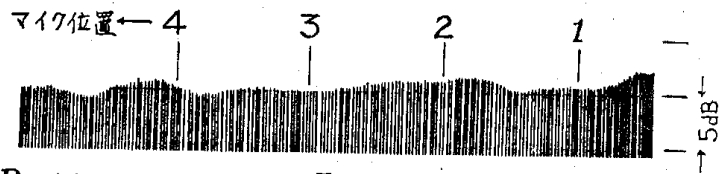

B 同上 15 回秒

W. $5.40 \mathrm{~dB} / \mathrm{sec}$.

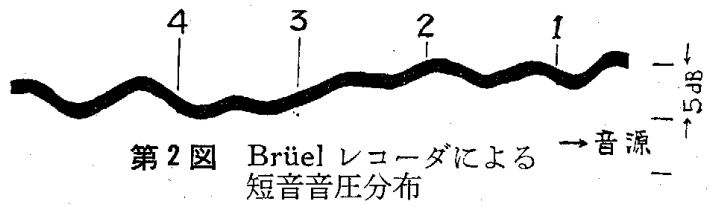

$3.15 \mathrm{kC} 1 / 3$ Oct. Noise 定常, W.5. $63 \mathrm{~dB} / \mathrm{sec}$.

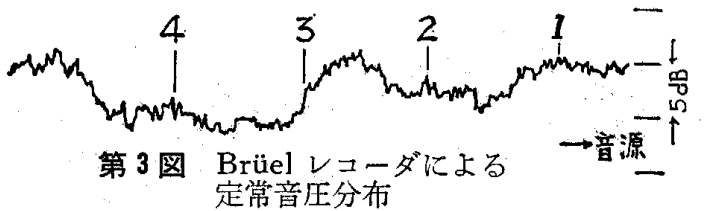

1) $3.15 \mathrm{kc}$ では山谷の形が非常によく似ているが、 $12.5 \mathrm{kc}$ では余り似ていない。

2）各周波数で定常態の山谷の比は、短音のものよりや や小さい。

3）短音減衰波形から、定常態の分布はほぼ想像できる が、その逆は不可能である。したがって第 1 図を求めて おけば、定常音圧分布 の測定を省略するとと ができよう。

4) しかし低音(実物 125 c/s）汶して拡散をよ くするためには、まず 定常音圧分布(第 3 図) を比較しながら、室形 を種々に変更して、一 様な分布に近づけるこ とが有力な手段となり 得るであろう。

1) 前川他; 建 ・論 66 号 193 (35年10月)

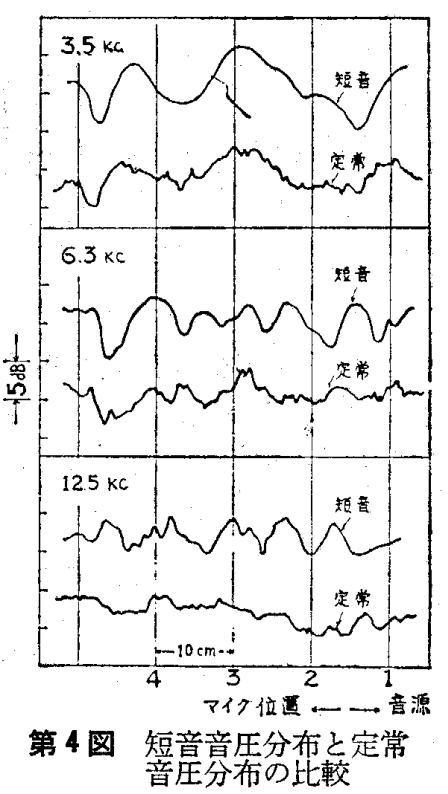

